\title{
Género Fusarium
}
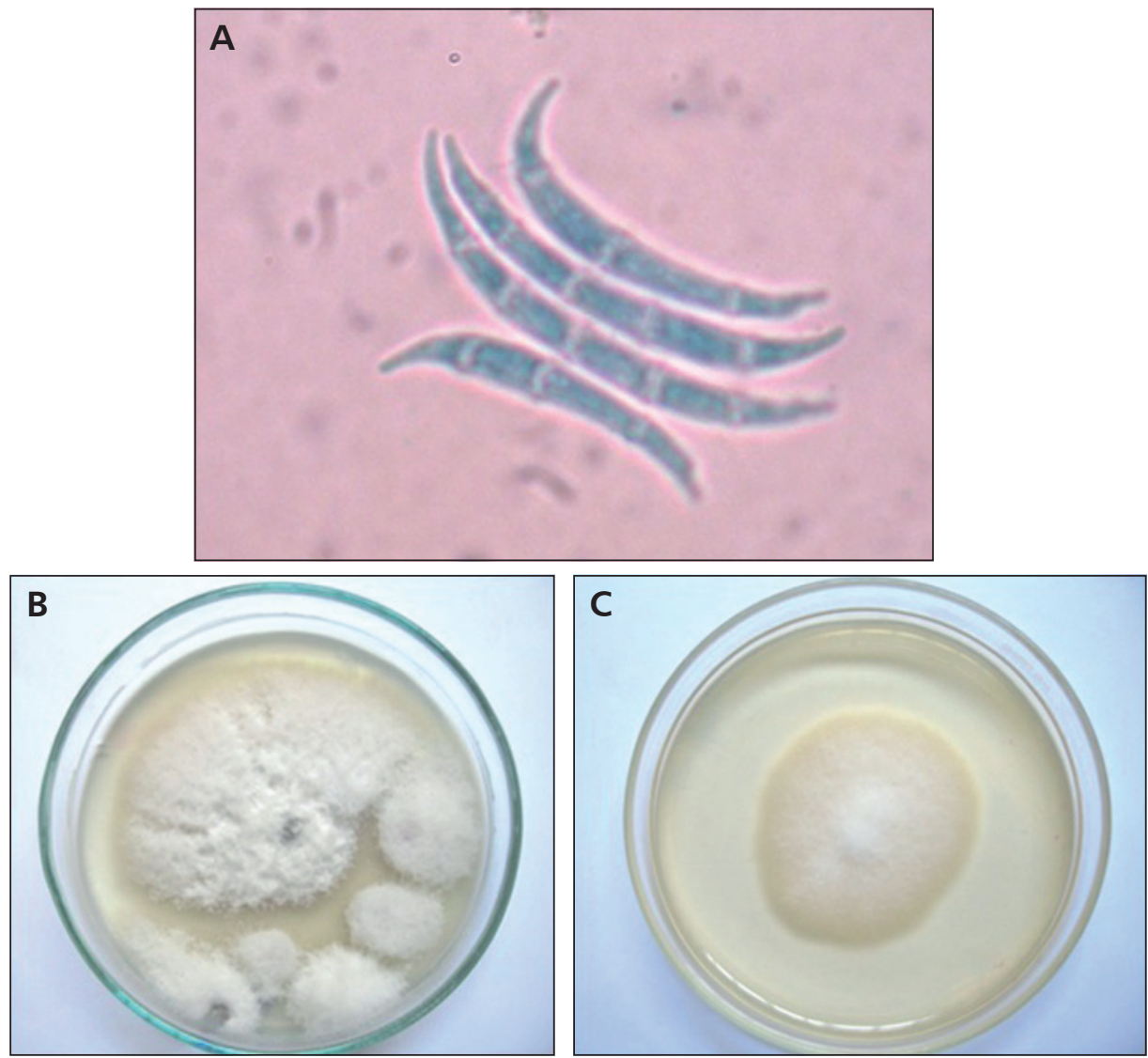

Figura 1. Fusarium sp. 1A: macroconidios de Fusarium sp. en aumento inmersión (100x). 1B: cultivo de Fusarium proliferatum en agar PDA. 1C: cultivo de Fusarium proliferatum en agar Sabouraud (Fotografía obtenida en Laboratorio de Micología Médica de la Universidad de Chile). 


\title{
Género Fusarium
}

El género Fusarium es un grupo de hongos filamentosos ampliamente distribuidos en el suelo y plantas. Debido a su capacidad de crecer a $37^{\circ} \mathrm{C}$, son considerados oportunistas. Pueden causar infecciones sistémicas en pacientes inmunocomprometidos, con una alta mortalidad. Algunas de sus especies producen toxinas que afectan al hombre y animales. De las más de 100 especies de Fusarium descritas, sólo 12 de ellas pueden considerarse patógenas para el humano, entre ellas destacan F. solani, F. oxysporum y F. verticilloides, en orden decreciente de frecuencia.

La taxonomía para este género es bastante compleja y ha sufrido diversos cambios desde las primeras descripciones hechas por Link en 1803. A pesar de los avances en la taxonomía molecular, y la aparición de metodologías como MALDI-TOF, la taxonomía clásica continúa vigente, aunque requiere de la experiencia del observador.

Al microscopio, la fiálide es generalmente fina, con forma de botella; simple o ramificada; cortas o largas; monofialídica (que emergen esporas de un poro de la fiálide) o polifialídica (de varios poros). Los macroconidios presentan forma de medialuna, hialinos y septados. Para su correcta clasificación es importante el largo, ancho, curvatura, septos, agrupaciones mucoides (esporodoquios) y detalles de las células de los extremos (célula apical y pie) (Figura 1A). Los microconidios, ausentes en algunas especies, poseen variadas formas (fusiformes, ovales, clavadas, entre otras), agrupaciones (estructuras mucoides llamadas "falsas cabezas"), en cadenas largas o cortas; todas observables a la lupa (40x). Otro tipo de conidios son los mesoconidios, que son similares pero de menor tamaño que los macroconidios y nunca forman estructuras mucoides. Por último, pueden observarse las clamidosporas características con doble pared gruesa, lisa o rugosa; de manera aislada, en pareja o en grupo.

Existen distintos medios que permiten su crecimiento; entre ellos, agar papa dextrosa (PDA), agar Sabouraud, agar Clavel (CLA), agar de Spezieller Nährstof-farmer (SNA) y agar avena. Los agares PDA y Sabouraud permiten observar el diámetro de la colonia, morfología y pigmento (café, rojo, violeta, naranja, gris, blanco) difusible al medio (Figura 1B y C), mientras que el agar CLA, permite observar el desarrollo de cadenas de microconidios y morfología en detalle de macroconidios (Figura 1A).

\section{Referencias bibliográficas}

1.- Leslie J F, Summerell B A. The Fusarium Laboratory Manual. Ed. Wiley- Blackwell. 2006.

2.- Piontelli, E. Manual de Microhongos filamentosos comunes I. 2011; 1: 261-80.

\author{
Cecilia Tapia y José Amaro \\ Programa de Microbiología y Micología \\ Instituto de Ciencias Biomédicas \\ Facultad de Medicina, Universidad de Chile.

